\title{
EFEKTIVITAS METODE THERAPEUTIC COMMUNITY DALAM PENCEGAHAN RELAPSE KORBAN PENYALAHGUNA NAPZA DI PANTI SOSIAL PAMARDI PUTRA GALIH PAKUAN BOGOR TAHUN 2017 Effectiveness of the Therapeutic Community Method in Preventing Drug Abuse Relapse in Panti Sosial Pamardi Putra Galih Pakuan Bogor, 2017
}

\author{
Irfan Ardani1 dan Heti Sri Hari Cahyani² \\ 1 Puslitbang Humaniora dan Manajemen Kesehatan Badan Penelitian dan Pengembangan Kesehatan \\ 2Program Magister Manajemen Pembangunan Sosial, Fakultas IImu Sosial dan IImu Politik Universitas Indonesia
}

Naskah masuk: 30 Januari 2019 Perbaikan: 4 Februari 2019 Layak terbit: 30 Juli 2019

http://dx.doi.org/10.22435/hsr.v22i3.1281

\begin{abstract}
ABSTRAK
Penyalahgunaan napza memiliki dampak buruk yaitu penularan penyakit dan ketidak berfungsian sosial akibat kecanduan napza. Rehabilitasi sosial dengan metode therapeutic community dianggap dapat membantu mengatasi kecanduan pada zat adiktif dan mengembalikan peran dan fungsi sosial para penyalahguna napza. Kendalanya adalah banyak penyalahguna napza mengalami relapse pasca rehabilitasi. Tujuan dari penelitian ini adalah mengetahui efektivitas pencegahan relapse dengan metode TC yang dilakukan oleh PSPP Galih Pakuan Bogor. Penelitian ini merupakan studi kasus dengan penyajian secara deskriptif analitis, dilakukan dengan wawancara mendalam kepada manajemen panti, Pekerja Sosial, dan klien, serta melakukan observasi dan analisis data sekunder. Hasil dari penelitian ini menunjukkan bahwa tingkat drop out rehabilitasi sosial di PSPP Galih Pakuan mencapai 44,8\% pada tahun 2017, sedangkan tingkat relapse diperkirakan mencapai $30 \%$ dari klien yang lulus rehabilitasi. Di sisi lain, berbagai penelitian menyebutkan bahwa metode TC merupakan metode yang relatif lebih efektif dibanding metode rehabilitasi sosial lain dalam mengurangi penyalahgunaan napza dan perilaku anti sosial akibat penyalahgunaan napza. Tantangan dalam metode TC adalah tingkat drop out yang cukup tinggi. Dibandingkan dengan metode rehabilitasi sosial lain, TC efektif meningkatkan keberfungsian sosial penyalahguna napza melalui penguatan individu dengan menumbuhkan kepercayaan diri, manajemen emosi dan spiritual.
\end{abstract}

Kata kunci: relapse, therapeutic community, efektivitas.

\begin{abstract}
Drug abuse has many adverse effects such as disease transmissions and social dysfunction. Social rehabilitation by therapeutic community method may overcome addictions to addictive substances and restore the social function for drug users. The problem is a post-rehabilitation relapse. Objective to determine the effectiveness of relapse prevention with the TC method carried out by PSPP Galih Pakuan Bogor. It is case study research, conducted by in-depth interviews with management, social workers, and clients, as well as observations and analysis of secondary data. Drop-out rates at PSPP Galih Pakuan reached $44.8 \%$ in 2017 , with relapse rate $30 \%$. In addition, many studies stated that the TC method was relatively more effective than other methods for social rehabilitation in reducing anti-social behavior due to drug abuse. The challenge in TC method is a high drop-out rate. TC method can improve the social functioning of drug users by fostering self-confidence, and learning emotional and spiritual management.
\end{abstract}

Keywords: relapse, therapeutic community, effectiveness.

Korespondensi:

Irfan Ardani

Puslitbang Humaniora dan Manajemen Kesehatan Badan Penelitian dan Pengembangan Kesehatan

E-mail: ardhani.irfan@gmail.com 


\section{PENDAHULUAN}

Badan Narkotika Nasional (BNN) memproyeksikan prevalensi penyalahgunaan narkotika, psikotropika dan zat adiktif (napza) di Indonesia tahun 2018 sebanyak 1,93 \% - 2,49 \% dari total penduduk (Badan Narkotika Nasional, 2015). Angka yang besar mengingat dampak buruk yang ditimbulkan akibat penyalahgunaan napza bagi diri maupun lingkungan sosialnya.

Napza terutama penggunaan jarum suntik merupakan salah satu faktor risiko penyebaran berbagai penyakit seperti infeksi HIVIAIDS dan Hepatitis C. Estimasi di tingkat global 2,8 juta pengguna napza suntik atau $17,8 \%$ dari total pengguna napza suntik positif terinfeksi HIV. Sedangkan estimasi pengguna napza suntik yang mengidap Hepatitis C sebanyak 8,2 juta atau 52,3\% dari total pengguna napza suntik (Degenhardt et al., 2017). Di Indonesia, 2\% dari Orang Dengan HIV/ AIDS (ODHA) merupakan pengguna napza suntik (Ditjen P2P Kementerian Kesehatan RI, 2017).

Upaya pemulihan bagi korban penyalahguna dan pencegahan penyalahgunaan diperlukan untuk mengurangi dampak buruk yang ditimbulkan akibat penyalahgunaan napza. Upaya penanggulangan penyalahgunaan napza di Indonesia tidak hanya fokus pada penegakan hukum saja, tetapi juga pada rehabilitasi penyalahguna napza. Penegakan hukum dilakukan untuk memberi efek jera dan menjatuhkan sanksi bagi pengedar dan penyalahguna napza. Dari sisi penegakan hukum, ribuan orang sebagai pengedar maupun bandar napza berhasil ditangkap aparat kepolisian dan divonis di pengadilan, dengan variasi hukuman baik hukuman penjara maupun hukuman mati.

Rehabilitasi bertujuan untuk menghilangkan dampak buruk dan pemulihan baik fisik maupun fungsi sosial akibat penyalahgunaan napza. Menurut Pasal 54 Undang Undang Nomor 35 Tahun 2009 Tentang Narkotika, upaya pemulihan dan mencegah pemakaian kembali (relapse) terhadap napza dilakukan melalui proses rehabilitasi, baik rehabilitasi medis maupun rehabilitasi sosial. Rehabilitasi medis bertujuan menghilangkan efek ketergantungan fisik akibat kecanduan napza melalui pengobatan terpadu. Rehabilitasi sosial bertujuan untuk mengembalikan keberfungsian sosial secara optimal bagi korban penyalahguna narkotika (Suharto, 2004). Banyak metode yang dikembangkan dalam upaya merehabilitasi sosial korban penyalahguna napza diantaranya program Therapeutic Community (TC), metode 12 Steps (dua belas langkah), metode obat herbal, maupun metode keagamaan.

Panti Sosial Pamardi Putra (PSPP) Galih Pakuan merupakan Unit Pelaksana Teknis rehabilitasi sosial bagi korban penyalahguna napza milik Kementerian Sosial Republik Indonesia. PSPP Galih Pakuan menerapkan metode Theraputic Community (TC) dalam layanan rehabilitasi sosialnya. Therapeutic Community adalah metode rehabilitasi sosial yang ditujukan kepada korban penyalahgunaan napza, dimana orang-orang dengan masalah dan tujuan yang sama, berkumpul sebagai sebuah "keluarga", sehingga terjadi perubahan tingkah laku ke arah yang positif, yaitu lepas dari ketergantungan napza (Direktorat Jenderal Pelayanan dan Rehabilitasi Sosial, 2003). Para penyalahguna napza yang mengikuti rehabilitasi sosial dengan metode TC akan belajar memahami dan menerapkan nilai-nilai positif yang menjadi struktur dan pilar TC selama kurun waktu tertentu sehingga diharapkan terjadi perubahan pola pikir, sikap, dan perilaku yang positif.

Metode TC menggunakan pendekatan sosial tanpa pemakaian obat-obatan dalam terapinya. Secara sosiologis, metode pendekatan sosial dianggap dapat membantu mengatasi kecanduan pada zat adiktif. Dalam metode TC ini, para penyalahguna napza akan belajar menghadapi masalah, memahami dan menerapkan nilai-nilai positif, serta menjalankan peran dan fungsi tertentu di panti.

Tujuan utama rehabilitasi sosial termasuk metode TC adalah pemulihan fisik maupun sosial dan mencegah penggunaan kembali (relapse) napza. Beberapa penelitian menyatakan bahwa metode TC lebih efektif dalam mencegah terjadinya relapse penyalahguna napza pasca rehabilitasi. Oleh karena itu penelitian ini bertujuan untuk mengetahui efektivitas pencegahan relapse dengan metode TC yang dilakukan oleh PSPP Galih Pakuan Bogor.

\section{METODE}

Penelitian kualitatif dilakukan di Panti Sosial Pamardi Putra Galih Pakuan Bogor dengan pendekatan studi kasus dan disajikan dalam bentuk deskriptif analitis. Pengumpulan data dilakukan pada bulan Maret sampai dengan Mei 2018 dengan teknik wawancara mendalam, observasi dan studi data sekunder. Instrumen yang digunakan adalah pedoman wawancara semi terstruktur dan daftar observasi. Wawancara mendalam dilakukan kepada 
3 (tiga) orang struktural panti, 4 (empat) orang klien panti, dan 3 (tiga) orang Pekerja Sosial yang menangani klien di PSPP Galih Pakuan. Klien adalah sebutan bagi penyalahguna napza yang tinggal dan mengikuti program terapi di PSPP Galih Pakuan. Validasi dilakukan dengan triangulasi sumber dan metode.

Informan pejabat struktural dipilih untuk mengetahui tugas dan fungsi panti sosial serta mengetahui hasil evaluasi internal pelaksanaan rehabilitasi sosial bagi korban penyalahguna napza yang ditangani. Informan Pekerja Sosial dipilih secara purposif dengan kriteria berpengalaman mendampingi klien penyalahguna napza dan pernah menangani klien yang mengalami relapse. Informan klien dipilih dengan kriteria pernah mengalami relapse, dan saat wawancara telah mengikuti kegiatan dalam panti sosial lebih dari satu bulan serta bersedia berpartisipasi dalam penelitian. Data sekunder berasal dari data laporan bulanan PSPP Galih Pakuan mulai dari bulan Januari sampai dengan Desember 2017 dan data literatur melalui pencarian internet.

\section{HASIL}

\section{Pelaksanaan program TC}

Metode TC menggunakan 4 struktur dan 5 pilar yang menjadi dasar pelaksanaan rehabilitasi sosial. Kurikulum rehabilitasi sosial mulai dari materi sampai metode pembelajaran didasarkan pada 4 struktur dan 5 pilar tersebut.

Empat struktur merupakan nilai-nilai yang ditanamkan kepada klien, sedangkan lima pilar merupakan cara menanamkan nilai-nilai tersebut. Setiap klien diwajibkan menghafalkan untuk kemudian mengamalkan 4 struktur dan 5 pilar ini sebagai bagian dari keseharian mereka. Untuk memudahkan klien menghafal, klien diwajibkan menuliskan semuanya dalam sebuah walking paper yang akan selalu mereka bawa selama masih di fase awal rehabilitasi (dikenal dengan fase induksi). Walking paper tersebut salah satunya berisi tentang nilai-nilai yang harus diterapkan oleh klien selama mengikuti rehabilitasi sosial dengan model TC. Nilai tersebut diantaranya adalah kejujuran, tanggung jawab, percaya pada lingkungan, timbal balik yang sepadan, dan memaafkan. Dalam pelaksanaan tugas keseharian dan selama mengikuti semua sesi terapi, klien diharuskan untuk mengamalkan nikainilai tersebut. Misalnya pada sesi function klien harus bertanggung jawab mengerjakan apa yang menjadi tugasnya. Selain itu pada sesi confrontation group dimana setiap orang diberi kesempatan menumpahkan emosi dan masalahnya terhadap klien lain, maka pada akhir sesi setiap klien harus mau saling memaafkan dan kembali bersikap baik seperti tidak ada masalah sebelumnya. Hal ini mengajarkan bahwa setiap masalah bisa diselesaikan melalui diskusi tanpa kekerasan.

\section{Tingkat kelulusan dan perubahan perilaku klien}

Berdasarkan data profil tahun 2017, PSPP Galih Pakuan menerima penyalahguna napza untuk mengikuti program rehabilitasi sosial (klien) sebanyak 411 orang dan memulangkan 326 orang klien. Sebagian besar klien yang menjalani rehabilitasi sosial berada pada umur produktif (usia 15 sampai

Tabel 1. Konsep Dasar Rehabilitasi Sosial dengan Metode Therapeutic Community

\begin{tabular}{ll}
\hline \multicolumn{1}{c}{ Struktur } & Therapeutic Community \\
\hline $\begin{array}{l}\text { Behaviour management shaping } \\
\text { (membentuk perubahan perilaku) }\end{array}$ & \multicolumn{1}{c}{ Pilar } \\
$\begin{array}{l}\text { Emotional and Psychological } \\
\text { (melatih kemampuan emosi dan psikologis) }\end{array}$ & $\begin{array}{l}\text { Family milleu concept } \\
\text { (pendekatan kekeluargaan) }\end{array}$ \\
$\begin{array}{l}\text { Intelectual and Spiritual } \\
\text { (peningkatan aspek intelektual dan spiritual) }\end{array}$ & $\begin{array}{l}\text { Peer Pressure } \\
\text { (perubahan perilaku melalui kelompok sebaya) }\end{array}$ \\
Vocational/ survival skill & $\begin{array}{l}\text { Therapeutic Session } \\
\text { (pembekalan keterampilan) }\end{array}$ \\
& $\begin{array}{l}\text { (jadwal kegiatan padat sehingga klien tidak memiliki waktu } \\
\text { senggang yang tidak bermanfaat) }\end{array}$ \\
& $\begin{array}{l}\text { Religious Class } \\
\text { (meningkatkan kualitas keimanan klien) }\end{array}$ \\
& $\begin{array}{l}\text { Role Model } \\
\text { (meningkatkan kepercayaan diri) }\end{array}$ \\
\hline
\end{tabular}


dengan 65 tahun) dengan klien paling banyak pada kelompok umur 21-25 tahun. Sabu-sabu menjadi napza yang paling banyak disalahgunakan oleh klien. Beberapa klien tidak hanya menggunakan satu jenis napza, bahkan ada yang menggunakan lima jenis napza sekaligus.

Tingkat keberhasilan klien dalam mengikuti rangkaian rehabilitasi sosial dengan metode TC di PSPP Galih Pakuan salah satunya dapat dilihat dari tingkat kelulusan klien. Kategori kelulusan dibagi dalam dua kriteria yaitu 1) lulus, yang berarti telah menyelesaikan tahapan program rehabilitasi; dan 2) drop out (DO) yaitu klien tidak menyelesaikan tahapan rehabilitasi sosial. Tingkat kelulusan klien dalam periode bulan Juli sampai dengan bulan Desember 2017 ditampilkan dalam grafik di bawah ini.

Grafik di atas memperlihatkan gambaran kelulusan klien antara bulan Juli sampai dengan Desember 2017. Gambaran bulan Januari sampai dengan Juni 2017 tidak dapat ditampilkan karena data yang ada tidak cukup menggambarkan penyebab kelulusan klien. Selama periode JuliDesember 2017 terdapat 44,8\% klien yang keluar dari proses rehabilitasi sosial di PSPP Galih Pakuan dengan status drop out rehabilitasi. Klien yang tidak menyelesaikan seluruh tahapan rehabilitasi disebabkan oleh dua alasan, yaitu klien kabur dan pemulangan atas permintaan pihak ketiga seperti permintaan keluarga, dipindahkan ke panti lain, dan putusan pengadilan.

Berdasarkan hasil wawancara dengan Kepala Seksi Rehabilitasi Sosial, permintaan keluarga yang menyebabkan klien tidak menyelesaikan rehabilitasinya biasanya terkait dengan kondisi yang sedang dihadapi keluarga. Umumnya berkaitan dengan faktor ekonomi, misalnya ada klien yang diminta pulang untuk menjadi tulang punggung keluarga menggantikan orang tuanya yang sakit. Dalam menanggapi permintaan dimaksud, pihak

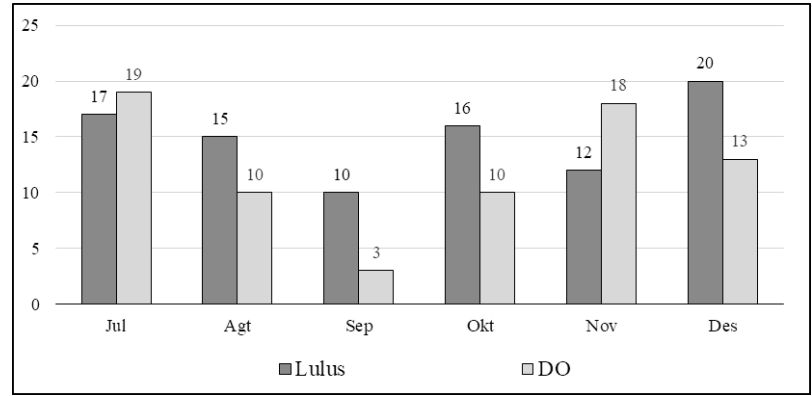

Gambar 1. Jumlah Klien Berdasarkan Jenis Kelulusan di PSPP Galih Pakuan Tahun 2017 panti akan melakukan case conference (CC) untuk membahas dan mengambil keputusan terhadap klien tersebut. Drop out juga bisa disebabkan oleh putusan pengadilan yang menjatuhkan rehabilitasi sebagai vonis hukuman. Putusan pengadilan yang berkekuatan hukum tetap mengharuskan klien yang belum selesai mengikuti tahapan TC (enam bulan) harus dipulangkan lebih awal karena masa hukuman yang sudah berakhir.

“... keputusan hakim menyatakan bahwa si $A$ harus direhabilitasi di PSPP Galih Pakuan selama 2 bulan, itu pernah terjadi...hasil sidangnya hanya 2 bulan...jadi harus dipulangkan (dipulangkan sebelum 6 bulan), kalo pengadilan tidak menyebutkan berapa bulannya ya sesuai aturan sini, minimal 6 bulan..." (Informan PSPP Galih Pakuan)

Alasan lain klien tidak menyelesaikan rehabilitasi adalah kabur dari panti karena tidak betah mengikuti kegiatan di panti yang sangat disiplin. Padatnya jadwal harian klien dari pagi sampai malam dan kurang kuatnya motivasi klien kadang membuat klien mudah merasa jenuh.

Selain dari tingkat kelulusan klien, keberhasilan metode TC juga dapat dilihat dari perubahan perilaku klien menjadi lebih baik. Sebagian besar informan yang berasal dari klien menyatakan bahwa ada perubahan perilaku yang dirasakan seperti kepercayaan diri yang meningkat dan mampu mengendalikan emosi.

“...dulu males sekarang jadi rajin, dulu gak bisa ngontrol emosi sekarang lebih dewasa, disini kita diajarkan untuk saling percaya, saling bantu, jadi kita saling percaya..., ngerasa lah ada perubahan, dulu gak bisa, apa, ngomong di depan orang, kalo disini mau naik tingkat kan harus seminar dulu, jadi belajar" (X, klien).

\section{Tingkat relapse}

Berdasarkan hasil wawancara mendalam dengan beberapa informan, diperkirakan tingkat relapse klien yang lulus dari rehabilitasi sosial di PSPP Galih Pakuan sebanyak 30\%. Dari data ini diasumsikan bahwa klien yang tidak lulus atau mengalami drop out berpotensi lebih tinggi untuk mengalami relapse daripada klien yang lulus mengikuti rehabilitasi. Sayangnya PSPP Galih Pakuan tidak memiliki data yang akurat yang mencatat kejadian relapse para alumninya. 
Persentase klien yang tidak menyelesaikan program TC dan persentase klien yang menggunakan kembali napza pasca program TC (relapse) menurut sebagian besar informan tidak dapat dikatakan bahwa rehabilitasi sosial dengan metode TC tidak efektif memulihkan klien dan mencegah relapse. Banyak faktor diluar proses rehabilitasi yang mempengaruhi kejadian relapse.

"Sebenarnya relapse atau tidak relapse akan tergantung pada masing-masing, apakah dia memang ingin sembuh atau gimana. Apakah niat dia itu kuat atau enggak, karena kalo kuat mau gimanapun diajak temen-temennya make lagi pasti mikir dua kali"(Konselor Adiksi)

"Jadi gini, di dunia manapun, yang namanya rehabilitasi, mau pake metode apapun, TC lah, 12 langkah lah, apapun, tidak ada yang bisa menjamin klien itu akan 100\% sembuh, jadi jangan dianggap kalo ada yang relapse berarti metode TC itu gak bagus, tapi emang banyak faktor lah" (Pekerja Sosial)

Menurut sebagian besar informan, masalah penyalahgunaan napza adalah masalah yang harus dilihat per kasus per individu. oleh karena itu tidak bisa diambil kesimpulan bahwa salah satu faktor penyebab akan lebih dominan daripada faktor penyebab lainnya. Semua tergantung pada masalah apa yang dialami oleh masing-masing klien, apakah berasal dari dalam diri sendiri atau dari lingkungannya.

Oleh karena itu, pembinaan lanjut pasca rehabilitasi dalam panti merupakan bagian penting dari proses resosialisasi penyalahguna napza supaya tidak mengalami relapse. Pembinaan lanjut yang dilakukan oleh PSPP Galih Pakuan masih terbatas hanya pada mantan klien dan keluarga saja, belum sampai pada lingkungan mantan klien, dan itupun belum menjangkau seluruh mantan klien. Tahun 2008 panti hanya mampu menjangkau $22,2 \%$ mantan klien, dan tahun 2010 hanya mampu menjangkau $32,2 \%$. Dari $22,2 \%$ mantan klien yang dijangkau melalui pembinaan lanjut tahun 2008 , sebanyak $3,5 \%$ nya mengalami relapse (Setiti, 2012).

\section{PEMBAHASAN}

Tujuan rehabilitasi dengan model TC adalah membantu seseorang menyadari potensi-potensi dirinya sehingga dapat memanfaatkan sarana dan prasarana yang diberikan untuk mengembangkan potensi-potensi tersebut secara maksimal. Pada akhirnya tujuan rehabilitasi adalah agar mereka yang menjalani rehabilitasi dapat melaksanakan fungsi sosialnya dengan optimal (Suharto, 2004). Meskipun demikian, hasil terhadap masing-masing klien akan berbeda satu dengan yang lain. Metode TC mengharuskan setiap penyalahguna napza untuk menetap di satu tempat yang sama (panti rehabilitasi sosial) untuk jangka waktu tertentu yang cukup lama. Idealnya TC berlangsung paling cepat satu tahun, bahkan bisa memakan waktu lebih lama. Dengan tinggal disatu tempat yang sama, klien memiliki kontak dengan setidaknya sebagian klien lain. Kontak ini menimbulkan perasaan positif dan kepedulian bersama antar klien. Nilai ini lah yang menjadi dasar therapeutic commmunity (Pearce \& Pickard, 2012).

\section{Kemampuan klien mengikuti program TC}

Selama bulan Juli sampai dengan Desember 2017, klien yang mampu mengkuti semua tahapan rehabilitasi sosial di PSPP Galih Pakuan adalah $55,2 \%$. Sedangkan $44,8 \%$ klien tidak mampu menyelesaikan tahapan rehabilitasi sosial. Hal ini selaras dengan penelitian George De Leon dan Harry Wexler (De Leon \& Wexler, 2009) bahwa sebagian klien program rehabilitasi sosial dengan model TC tidak menyelesaikan lama perawatan seperti yang sudah direncanakan. Tingkat retensi atau kemampuan bertahan klien adalah 30 hingga $45 \%$. Menurut Marion Malivert dkk (Malivert, Fatseas, Denis, Langlios, \& Auriacombe, 2012) berdasarkan hasil dari enam penelitian, 9-56\% klien mampu menyelesaikan semua tahapan TC. Sebanyak 27$70 \%$ klien mampu bertahan setidaknya $50 \%$ dari waktu yang direncanakan dalam program TC. Putus program (DO) paling banyak terjadi di empat bulan awal rehabilitasi, dan tertinggi terjadi dalam 30 hari pertama masa rehabilitasi (Stelle, Blumer, \& Moberg, 2004). Faktor yang paling mempengaruhi tingkat retensi ini adalah motivasi dan kesiapan klien dalam mencari pengobatan. Tanpa motivasi yang kuat untuk mengikuti rehabilitasi, klien sangat rawan terhadap kebosanan yang mempengaruhi tingkat kepatuhan mengikuti proses rehabilitasi dan adanya kemungkinan penggunaan napza kembali (relapse) (Setiti, 2012). 


\section{Tingkat Relapse Pasca Program Tc}

Relapse pada penyalahguna napza pasca rehabilitasi di berbagai negara menunjukkan kecenderungan cukup tinggi. Sebagian relapse terjadi pada tahun pertama setelah menyelesaikan rehabilitasi. Sebanyak $35-95 \%$ klien mengalami relapse setelah 3 bulan rehabilitasi (Appiah, Danquah, Nyarko, Ofori-Atta, \& Aziato, 2017), dan $15 \%$ - 45\% mengalami relapse 24 bulan setelah rehabilitasi (Herd \& Borland dalam Appiah et al., 2017). Penelitian lain menemukan relapse terjadi tiga hari pasca rehabilitasi sebesar 34\% (Gossop, Stewart, Browne, \& Marsden, 2002). Sebagian besar relapse penyalahguna napza melibatkan penggunaan ganja $(37,4 \%)$, kokain $(31,6 \%)$, heroin $(18,7 \%)$, dan benzodiazepin (15,5\%) (Montalvo, Goni, Illescas, Landa, \& Lorea, 2007).

Proses relapse adalah kembalinya seseorang kepada kecanduan napza. Kondisi relapse terjadi jika seorang mantan penyalahguna napza yang telah pulih kembali menyalahgunakan napza setelah sebelumnya ia berhasil menjalani pemulihan dari ketergantungan. Relapse merupakan suatu proses yang progresif yang melibatkan proses emosi dan behavioral dari individu dimana pada akhirnya ia kembali pada kondisi seperti sebelum ia menerima perawatan dari kecanduannya (Purnomo \& Hardjanto, 2016). Menurut Marlatt dan Gordon (dalam Ibrahim, Samah, Talib, \& Sabran, 2012) relapse berawal dari faktor-faktor yang dinamakan situasi berisiko tinggi (high risk situation). Situasi berisiko tinggi ini terdiri dari tiga keadaan yaitu emosi negatif, mengalami konflik interpersonal, dan menghadapi tekanan sosial dari lingkungan mantan penyalahguna napza.

Ada dua faktor utama yang mempengaruhi terjadinya relapse pasca rehabilitasi pada penyalahguna napza yaitu faktor intrapersonal dan faktor interpersonal (Marlatt \& Witkiewitz, 2005). Faktor intrapersonal atau faktor internal merupakan faktor yang berasal dari dalam diri individu, diantaranya meliputi rasa percaya diri, motivasi, keadaan emosi, dan harapan. Sedangkan faktor interpersonal atau faktor eksternal merupakan dukungan sosial (termasuk stigma) yang memainkan peran penting sebagai penentu seorang penyalahguna napza mengalami relapse. Dukungan sosial yang positif terutama dari lingkungan terdekat yakni orang tua, saudara, dan teman dekat dalam jangka panjang sangat mempengaruhi seseorang untuk menjauhi beberapa perilaku adiktif seperti penyalahgunaan narkoba (Cristiano, 2004). Sebaliknya, stigma sosial yang menyifatkan penyalahguna napza sebagai "tercela" dan "berbahaya" akan mendorong penyalahguna napza tersebut secara mental menganggap dirinya sebagai seseorang yang tidak diinginkan ada di masyarakat (Phillips, 2011). Stigma ini menjadi faktor yang cukup dominan sebagai penyebab relapse.

\section{Efektivitas pencegahan relapse program TC dibandingkan program lain}

Menurut manajemen PSPP Galih Pakuan, diperkirakan $30 \%$ klien yang lulus dari program TC mengalami relapse. Artinya program TC yang diterapkan belum mampu mencegah $100 \%$ terjadinya relapse. Akan tetapi, pada dasarnya kejadian relapse tidak berarti program pemulihan kecanduan melalui TC yang dijalani gagal. Beberapa penelitian menyatakan bahwa metode TC relatif lebih efektif dibanding metode lain dalam penanganan masalah penyalahgunaan napza. Hasil systematic review Vanderplasschen dkk (Vanderplasschen et al., 2013) menunjukkan bahwa dua dari tiga penelitian menyatakan TC lebih baik dalam pemulihan penyalahguna napza dibanding dengan intervensi lain pada saat tindak lanjut pertama setelah perawatan. Studi lain yang dilakukan De Leon (De Leon \& Wexler, 2009), tindak lanjut yang dilakukan dalam rentang 1 sampai 12 tahun pasca rehabilitasi memperlihatkan bahwa TC dengan metode residensial jangka panjang efektif dalam mengurangi penyalahgunaan napza dan perilaku antisosial, khususnya pada pengguna opioid. Penelitian Malivert dkk (Malivert et al., 2012) juga menemukan bahwa dengan metode TC menunjukkan penurunan yang signifikan dalam penggunaan napza oleh klien selama progam berlangsung dan tergantung pada lamanya masa rehabilitasi. Metode TC efektif dalam mengurangi relapse penyalahguna napza sebesar $70 \%$ dibanding alternatif program lain (Galassi, Mpofu, \& Athanasou, 2015). Rehabilitasi dengan model residensial secara substansial meningkatkan kemungkinan abstinen (berpantang) dari penggunaan napza, terutama ketika klien memiliki hubungan yang baik dengan penyedia layanan (McKetin et al., 2018).

Rehabilitasi sosial model TC di PSPP Galih Pakuan seharusnya tidak berhenti pada proses rehabilitasi di dalam panti saja, tetapi juga harus memperhatikan proses pembinaan lanjut di luar panti dengan melibatkan lingkungan sosial. Sehingga bimbingan lanjut bagi mantan penyalahguna napza, keluarga, dan lingkungan sangat penting dilakukan 
dalam rangka monitoring dan menjaga kondisi kepulihan penyalahguna napza yang telah selesai menjalani program rehabilitasi.

\section{KESIMPULAN DAN SARAN}

\section{Kesimpulan}

Rehabilitasi sosial dengan metode Therapeutic Community (TC) di PSPP Galih Pakuan mampu meningkatkan keberfungsian sosial penyalahguna napza melalui penguatan individu yang dilakukan dalam panti dengan menumbuhkan kepercayaan diri, manajemen emosi dan spiritual melalui serangkaian terapi dan kegiatan. Tantangan yang ada adalah tingkat drop out yang masih tinggi, serta tingkat relapse yang cukup tinggi. Meskipun demikian, berbagai penelitian menyebutkan bahwa metode TC merupakan metode yang lebih efektif dibanding metode rehabilitasi sosial lain dalam mengurangi penyalahgunaan napza dan perilaku anti sosial akibat penyalahgunaan napza.

\section{Saran}

Rehabilitasi sosial melalui TC dalam panti merupakan upaya pemulihan intrapersonal penyalahguna napza untuk menumbuhkan dan mengembalikan rasa percaya diri, motivasi, keadaan emosi, dan harapan positif agar terbebas dari kecanduan napza. Selain pemulihan intrapersonal, untuk mencegah relapse dibutuhkan pula dukungan faktor eksternal berupa dukungan sosial yang positif terutama dari lingkungan terdekat yakni orang tua, saudara, dan teman dekat dalam jangka panjang. Oleh karena itu, panti rehabilitasi sosial juga harus mengembangkan metode untuk memberdayakan lingkungan sosial dimana mantan penyalahguna napza berada, sehingga nilai-nilai positif yang didapatkan klien selama program TC dalam panti tetap dapat dilaksanakan di luar panti dan mendapatkan dukungan positif dari lingkungan sosialnya.

\section{UCAPAN TERIMA KASIH}

Ucapan terima kasih kepada Dr. Ir. R. Harry Hikmat, M.Si. dari Kementerian Sosial Republik Indonesia yang telah memberikan bimbingan dan masukan dalam penelitian ini. Penulis juga menyampaikan terimakasih kepada segenap jajaran PSPP Galih Pakuan Bogor, segenap Pekerja Sosial dan Konselor, serta klien yang mau berpartisipasi dan berbagi pengalaman hidup mereka dalam penelitian ini.

\section{DAFTAR PUSTAKA}

Appiah, R., Danquah, S. A., Nyarko, K., Ofori-Atta, A. L., \& Aziato, L. 2017. Precipitants of Substance Abuse Relapse in Ghana: A Qualitative Exploration. Journal of Drug Issues, 47 (1), 104-115. available at: https:// doi.org/10.1177/0022042616678612

Badan Narkotika Nasional. 2015. Laporan Akhir Survey Nasional Perkembangan Penyalahguna Narkoba Tahun Anggaran 2014. Jakarta.

Cristiano, J. 2004. Impact of Social Support on Drug Relapse Levels of Parolees Who Participated in An In-prison Therapeutic Community. University of California.

De Leon, G., \& Wexler, H. 2009. The Therapeutic Community for Addictions: an Evolving Knowledge Base. The Journal of Drug Issues, 39 (1), 167-178. available at: https://doi.org/10.1177/002204260903900113

Degenhardt, L., Peacock, A., Colledge, S., Leung, J., Grebely, J., Vickerman, P., ... Larney, S. 2017. Global prevalence of injecting drug use and sociodemographic characteristics and prevalence of HIV, HBV, and HCV in people who inject drugs: a multistage systematic review. The Lancet Global Health, 5 (12), e1192-e1207. https://doi.org/10.1016/ S2214-109X(17)30375-3

Direktorat Jenderal Pelayanan dan Rehabilitasi Sosial. 2003. Metode Therapeutic Community, (Komunitas Terapeutik) dalam rehabilitasi sosial penyalahgunaan narkoba. Jakarta, Badan Narkotika Nasional bekerja sama dengan Direktorat Jenderal Pelayanan dan Rehabilitasi Sosial Departemen Sosial RI.

Ditjen P2P Kementerian Kesehatan RI. 2017. Laporan Situasi perkembangan HIV-AIDS \& PIMS di Indonesia Januari-Maret 2017. Jakarta.

Galassi, A., Mpofu, E., \& Athanasou, J. 2015. Therapeutic Community Treatment of an Inmate Population with Substance Use Disorders: Post-Release Trends in Re-Arrest, Re-Incarceration, and Drug Misuse Relapse. International Journal of Environmental Research and Public Health, (12), 7059-72. https:// doi.org/10.3390/ijerph120607059

Gossop, M., Stewart, D., Browne, N., \& Marsden, J. 2002. Factors associated with abstinence, lapse or relapse to heroin use after residential treatment: protective effect of coping responses. Addiction, 97 (10), 1259-67. https://doi.org/10.1046/j.1360-0443.2002.00227.x

Ibrahim, F., Samah, B. A., Talib, M. A., \& Sabran, M. S. 2012. Penagih Dadah dan Keadaan Berisiko Tinggi Kembali Relaps (Drug Addicts and the High Risk Situations of Relapse. Journal of Social Sciences and Humanities, 7(1). 
Malivert, M., Fatseas, M., Denis, C., Langlios, E., \& Auriacombe, M. 2012. Effectiveness of Therapeutic Communities: A Systematic Review. European addiction research, 18(1). https://doi. org/10.1159/000331007

Marlatt, G. A., \& Witkiewitz, K. 2005. Relapse Prevention for Alcohol and Drug Problems. In G. A. Marlatt \& D. M. Donovan (Ed.), Relapse Prevention: Maintenance Strategies in the Treatment of Addictive Behaviors (2nd ed.). New York: The Guilford Press.

McKetin, R., Kothe, A., Baker, A. L., Lee, N. K., Ross, J., \& Lubman, D. I. 2018. Predicting Abstinence from Methamphetamine Use After Residential Rehabilitation: Findings from the Methamphetamine Treatment Evaluation Study. Drug and Alcohol Review, 37 (1), 70-78. https://doi.org/10.1111/dar.12528

Montalvo, J. F., Goni, J. J. L., Illescas, C., Landa, N., \& Lorea, I. 2007. Relapse Precipitants in Addictions: Results in a Therapeutic Community. Journal of Addictive Diseases, 26 (4), 55-61. https://doi.org/10.1300/ J069v26n04_07

Pearce, S., \& Pickard, H. 2012. How therapeutic communities work: Specific factors related to positive outcome. International Journal of Social Psychiatry, 59 (7), 636645. https://doi.org/10.1177/0020764012450992

Phillips, L. A. 2011. Stigma And Substance Use Disorders: Research, Implications, And Potential Solutions.
Journal of Drug Addiction, Education, and Eradication, 7 (2), 91-99. available at: http://search.proquest.com/ docview $/ 1728422578$ ?accountid $=17242$

Purnomo, I. D., \& Hardjanto, G. 2016. Terapi dengan Pendekatan Konsep Kognitif Perilaku untuk Mencegah Relapse pada Pengguna Narkoba. Jurnal Hukum Khaira Ummah, 15 (1).

Setiti, S. G. 2012. Evaluasi Pelaksanaan Rehabilitasi Sosial Panti Sosial Pamardi Putra (PSPP) Galih Pakuan Bogor. In N. Widodo (Ed.), Evaluasi Pelaksanaan Rehabilitasi Sosial Pada Panti Sosial: Pembinaan Lanjut (After Care Services) Pasca Rehabilitasi Sosial. Jakarta, P3KS Press.

Stelle, K. R., Blumer, C., \& Moberg, P. 2004. Treatment Retention of Dually Diagnosed Offenders In An Institutional Therapeutic Community. Behavioral Sciences and the Law, 22, 585-597. https://doi. org/10.1002/bsl.602

Suharto, E. 2004. Isu-Isu Tematik Pembangunan Sosial: Konsepsi dan Strategi. Jakarta, Badan Pelatihan dan Pengembangan Sosial.

Vanderplasschen, W., Colpaert, K., Autrique, M., Rapp, R. C., Pearce, S., Broekaert, E., \& Vandevelde, S. 2013. Therapeutic Communities for Addictions: A Review of Their $\mathrm{E} \square$ ectiveness from a Recovery-Oriented Perspective. The Scientific World Journal, 2013. https://doi.org/10.1155/2013/427817 